\title{
THE INFLUENCE OF EMPLOYEE SATISFACTION ON SAFETY AND PRODUCTIVITY \\ UDC 159.942.4:331.103.3
}

\author{
Tomislav Rakić ${ }^{1}$, Snežana Živković \\ ${ }^{1}$ TommyR Corptex d.o.o. Leskovac, Serbia \\ ${ }^{2}$ Faculty of Occupational Safety in Niš, University of Niš, Niš, Serbia
}

\begin{abstract}
The satisfaction of an employee has great influence on his/her motivation to increase productivity. Motivation is one of the most important topics in management because organizations achieve certain results and goals depending on employee performance which is, again, directly related to employee satisfaction. The focus of human activities and their driving force is the complex combination of factors that comprise all the motivational drivers. In an effort to answer the question of why an individual behaves in a particular way and not otherwise, it is necessary to analyze the motives which are the components of each personality.

It is possible to explore practical ways to eliminate or reduce the effects of factors that cause undesired motivation if objective stimuli from working environment are identified. As employee satisfaction involves multiple factors, the primary goal of this paper is to identify employee needs and then rank them. The results presented in this paper are part of an extensive survey first conducted in 2014/2015, and repeated in 2018, on a total sample of 386 respondents.
\end{abstract}

Key words: motivation, workplace safety motivation, work incentive, job satisfaction

\section{INTRODUCTION}

Being regulated by a variety of motives is a characteristic of human beings; also, human activity is governed by a large number of needs. Therefore, the focus of human activity and their driving force represent a combination of different factors composed of various drivers. In order to get the proper answer to the question of why an individual behaves in a certain way in a particular situation and not differently, it is necessary to analyse motives as constituent parts of each personality. It is also necessary to determine the motives of deliberate rule-breaking behaviour and exposing oneself to great danger.The ultimate aim is to understand the motives which cause healthy people behave the way they do. Research on

Received September 9, 2019 / Accepted September 23, 2019

Corresponding author: Snežana Živković

Faculty of Occupational Safety. Čarnojevića 10a, 18000 Niš, Serbia

E-mail: snezana.zivkovic@znrfak.ni.ac.rs 
practical ways for eliminating or decreasing the effect of factors that cause unwanted motivation is possible by identifying the incentives from work environment.

\subsection{Defining workplace safety motivation}

Motivation is defined as a process of driving human activities, directing them towards certain objects and regulating the activities with the aim to achieve certain goals. Motivation represents a psychological peculiarity of people which influences the level of an individual's dedication to accomplishing certain work or activity [28]. Motivation is determined as a force that strengthens behaviour, defines the behavioural path and causes the tendency to continue with that kind of behaviour [3]. Saraswathi explains the term motivation as readiness to show high level of effort directed towards organizational aims with the ability to fulfill the individual needs [24]. Employee motivation represents one of the main management policies used to increase work efficiency among employees in the organization [25]. Motivation consists of factors that cause, channel and support human behaviour in the wanted direction [15]. Numerous definitions of motivation in literature have certain similarities which show that individual motivation starts with a desire to achieve something particular, it continues with physical activity, and then mental confirmation of desire fulfilment [35].

Workplace safety motivation is frequently observed from the value and expectation point of view, meaning that motivation for workplace safety depends on the attitudes and values related to safety [9]. Rogers' theoretical model of safety motivation describes workplace safety motivation as a direct function of employee motivation to protect oneself [23]. This motivation implies the sensitiveness to injuries, severity of consequences from injuries, the measures for preventing the risk of injuries, the reasons the staff are not complying with the measures and work procedures, etc.

Workplace safety motivation is conceptualized as being an aim-oriented. The very process of setting goals and its achievement implies that workplace safety motivation is the main precondition for safe behaviour. In other words, safety motivation could be better understood as a combination of values, attitudes and aims which employees use to "make" their own motivation for practice and behaviour related to occupational safety. Workplace safety motivation is determined as an individual's readiness to make effort and accept safe behaviour [20]. There is a causal relationship between workplace safety motivation and behaviour - the stronger the motivation among the employees, the more they are ready to behave in a safe manner at work [6]. Therefore, workplace safety motivation is essential for creating a safe work environment [14]. Other authors define safety motivation as individual factors that initiate, channel and maintain behaviour outcomes in order to accomplish a certain goal - to behave safely at work $[33,1]$.

The purpose of workplace safety motivation is to prevent injuries and accidents by applying scientific methods and procedures. This kind of motivation influences safety procedures and enables safety for an individual and organization [34].

Numerous surveys have investigated the effect of workplace safety motivation on the number of injuries and accidents. The results show that the organizations can, directly or indirectly, influence the employees who do not follow the regulations and procedures for safe work, and in that way improve their motivation for workplace safety [20, 7, 29]. Zohar states that the lack of safety motivation can have impact on unsafe work behaviour and consequently, work-related injuries and accidents [31]. 
Surveys show that different aspects, such as aims, leadership, safe atmosphere, participation of the employees in informal activities related to occupational safety (conversations with colleagues about safety) and complying with the standards and regulations for occupational safety (work procedures and safe equipment) are related to employee safety motivation [21, 20, $12,11]$. The studies prove that employee safety behaviour is very much determined by their motivation for safety in the workplace [7, 20, 21]

Studies that examined the relationship between leadership and workplace safety motivation showed that there is a mutual connection between them [2, 12, 13]. The connection of an employee with the company management in terms of safety issues or showing interests for employee opinion regarding work safety generally increases safety motivation and encourages employee safe behaviour $[18,4,5]$.

Leadership can be observed as a starting point for safety motivation. Management is responsible for setting up the goals, a safe work environment, employee motivation for safe behaviour, and an efficient line of communication in the whole organisation. Besides, management is responsible for giving good examples of how to comply with safety measures and general safety, as well as how to create and maintain safe atmosphere. This implies that managers should be led by their own example in order to make sure that all other employees have enough knowledge about regulations in occupational safety and safe work environment. Also, this includes safety concerns as a part of everyday activities. Therefore, management is responsible for establishing clear and specific but reachable goals of protection and safety in an organisation.

From an employee's point of view, favourable safe atmosphere means that everyone is responsible for safe performance in the workplace and that employees should help each others to finish their jobs and assignments in accordance with safety measures. In other words, the concept of safe atmosphere refers to a procedure, practice, and perception of workplace policy, which is extremely related to workplace safety motivation.

The available literature on the subject of safety motivation at workplace mostly examines the coordination between psychophysical conditions, desires and expectations of a certain person with the workplace requirements and characteristics, all based on the existing knowledge and empirical investigations. Literature related to adaptability and individual satisfaction and conditions for employee safety and optimal efficiency of the work process is far less available [19, 16, 26, 30, 27, 32].

Frequently, comprehensive regulations related to the work environment can impose numerous obligations on an employer. As a consequence, it is hard to implement all predicted measures and regulations, especially in case of minor and medium companies due to the lack of knowledge, time or finances. Another reason for not complying with the workplace rules and the reason for injuries and accidents at workplace is the lack of motivation for safety i.e. occupational safety. To confirm this, for example, the investigation conducted by Kwon and Kim claims that there is often a lack of motivation for health and safety measures in an organisation [17].

According to Dejoy's statements, there are two major psychological approaches for improving occupational safety - the first one, safety initiations based on behaviour and the second, strategies of safety culture [8]. Both approaches aim at improving workplace safety motivation and safe work; however, these two approaches are based on different philosophical approaches that best motivate the employees to apply safety measures and safe performance in the workplace. Employees are usually motivated through different 
techniques (e.g. awards and stimulations), whereas, developing positive safety culture is more based on the values which encourage the employees to adopt and accept specific values of occupational safety. Since both approaches are efficient in improving occupational safety, it can be concluded that there are different forms of motivation for workplace safetyone type of motivation led by outer rewards (or punishment) and the second one which is based on employees' perception of the significance of occupational safety.

\section{RESEARCH METHODOLOGY}

The subject of this investigation is to investigate a complex phenomenon of workplace safety motivation and the hierarchy of motives and factors which affect the employee motivation for occupational safety in Serbian social and organisational conditions.

The following scientific methods have been used:

1. Questionnaire method

The questionnaire is the main method by which the subjective attitudes of employees were investigated.

As an instrument of investigation, the modified scale for measuring safety motivation was used [32], and it consisted of 40 questions.

Question number 9 includes seven employee incentives (income, permanent employment, interpersonal relations, personal needs, occupational safety, work content, participation in decision making). The employees are required to rank the incentives numerically, from 1 to 5 .

2. Statistical methods:

The following statistical methods were used:

- Frequency

- Percentage

- Cumulative percentage

- Rank

- Standard deviation

- Correlation coefficient

- Paired sample T-test

- ABC diagram.

Statistic data processing was done by a program package for statistical data analysis SPSS for Windows 19.0.

3. The sample of investigation

The sample of the investigation consisted of 386 employees in companies 'Kontejnerski transport i generalni tereti' (KTGT) Bar, "Port of Adria" AD Bar and "Luka Bar" AD, Montenegro. The sample included examinees from various areas of work, of different gender, age, and years of service [22]. 


\section{RESULTS AND DISCUSSION}

Based on the collected data processed by analytical software SPSS, the following results were obtained:

\section{- Income}

Table 1 Work incentives - income [22]

\begin{tabular}{|c|c|c|c|c|}
\hline & & $\begin{array}{c}\text { AD KTGT Bar } \\
2015 \\
\end{array}$ & $\begin{array}{c}\text { Port of Adria } \\
2018 \\
\end{array}$ & $\begin{array}{c}\text { Luka Bar } \\
2018\end{array}$ \\
\hline \multirow{6}{*}{ Valid } & No effect & $7.61 \%$ & $5.6 \%$ & $4.00 \%$ \\
\hline & Small effect & $9.78 \%$ & $7.4 \%$ & $4.00 \%$ \\
\hline & Medium effect & $23.91 \%$ & $31.5 \%$ & $16.00 \%$ \\
\hline & Large effect & $14.13 \%$ & $9.3 \%$ & $36.00 \%$ \\
\hline & Very large effect & $44.57 \%$ & $46.3 \%$ & $40.00 \%$ \\
\hline & Total & $100.00 \%$ & $100.00 \%$ & $100.00 \%$ \\
\hline
\end{tabular}

Analysing the above listed results, especially when it comes to comparing two completely opposite views - the absence of effect and small effect of income as work incentive on one hand, and large or very large effect of income on the other, it can be noticed that $17.39 \%$ of examinees in AD KTGT BAR do not consider income as a work incentive or its effect is small, whereas $58.70 \%$ of examinees think that income has a large or very large effect on work. In company Port of Adria, for $13 \%$ of examinees, the income is not a work incentive or it has small effect in contrast to $55.60 \%$ of the examinees for whom income is a very important work incentive. In company Luka Bar, only $8 \%$ opine that income is a work incentive or it has small effect, in comparison to $76.00 \%$ of their examined colleagues, to whom income has as a large or very large effect.

Based on the obtained distribution of answers, the conclusion is unambiguously imposed: the income for the examinees in all companies has a very large effect on work motivation.

\section{- Permanent employment}

Table 2 Work incentives - permanent employment [22]

\begin{tabular}{|c|c|c|c|c|}
\hline & & $\begin{array}{c}\text { AD KTGT Bar } \\
2015\end{array}$ & $\begin{array}{c}\text { Port of Adria } \\
2018 \\
\end{array}$ & $\begin{array}{c}\text { Luka Bar } \\
2018\end{array}$ \\
\hline \multirow{6}{*}{ Valid } & No effect & $6.52 \%$ & $7.4 \%$ & $12.00 \%$ \\
\hline & Small effect & $15.22 \%$ & $11.11 \%$ & $4.00 \%$ \\
\hline & Medium effect & $20.65 \%$ & $24.07 \%$ & $8.00 \%$ \\
\hline & Large effect & $14.13 \%$ & $12.96 \%$ & $32.00 \%$ \\
\hline & Very large effect & $43.48 \%$ & $44.44 \%$ & $44.00 \%$ \\
\hline & Total & $100.00 \%$ & $100.00 \%$ & $100.00 \%$ \\
\hline
\end{tabular}

In company AD KTGT Bar, for $21.74 \%$ of the examinees, permanent employment is not considered as a work incentive or its effect is small, whereas, for $57.61 \%$ of the examinees, permanent employment has a large or very large effect on work incentive. In 
Port of Adria, $18.51 \%$ of the examinees think that permanent employment is a work incentive or it has a small effect, in comparison to $57.40 \%$ of examinees for whom permanent employment has large or very large effect on work incentive. In Luka Bar, permanent employment is not a work incentive or it has small effect, in comparison to $76.00 \%$ of their colleagues to whom permanent employment represents large or very large effect as work incentive.

Permanent employment has a large effect on work motivation in all three groups of the examinees.

\section{- Interpersonal relations}

Table 3 Work incentives - interpersonal relations [22]

\begin{tabular}{|c|c|c|c|c|}
\hline & & $\begin{array}{c}\text { AD KTGT Bar } \\
2015\end{array}$ & $\begin{array}{l}\text { Portof Adria } \\
2018\end{array}$ & $\begin{array}{c}\text { Luka Bar } \\
2018\end{array}$ \\
\hline \multirow{6}{*}{ Valid } & No effect & $6.52 \%$ & $0.00 \%$ & $4.00 \%$ \\
\hline & Small effect & $7.61 \%$ & $7.41 \%$ & $4.00 \%$ \\
\hline & Medium effect & $28.26 \%$ & $27.78 \%$ & $36.00 \%$ \\
\hline & Large effect & $32.61 \%$ & $33.33 \%$ & $32.00 \%$ \\
\hline & Very large effect & $25.00 \%$ & $31.48 \%$ & $24.00 \%$ \\
\hline & & $100.00 \%$ & $100.00 \%$ & $100.00 \%$ \\
\hline
\end{tabular}

In AD KTGT Bar, interpersonal relations has no or small effect for $14.13 \%$ of the examinees, whereas $57.61 \%$ think that interpersonal relations have large or very large effect as a work incentive. In Port of Adria, for $7 \%$ of the examinees, interpersonal relations have minimum effect in comparison to $64.81 \%$ of examinees for whom they have large or very large effects. In Luka Bar, for $8.00 \%$ of the examinees interpersonal relations have no or small, while $56.00 \%$ of their colleagues opine that interpersonal relations have large or very large effects.

Interpersonal relations are considered a work incentive which has a large or very large effect on work motivation for most of the examinees from all three companies.

\section{- Personal needs}

Table 4 Work incentive - personal needs

\begin{tabular}{|c|c|c|c|c|}
\hline & & $\begin{array}{c}\text { AD KTGT Bar } \\
2015\end{array}$ & $\begin{array}{c}\text { Port of Adria } \\
2018\end{array}$ & $\begin{array}{c}\text { Luka Bar } \\
2018\end{array}$ \\
\hline \multirow{6}{*}{ Valid } & No effect & $10.87 \%$ & $5.56 \%$ & $4.00 \%$ \\
\hline & Small effect & $11.96 \%$ & $7.41 \%$ & $16.00 \%$ \\
\hline & Medium effect & $20.65 \%$ & $31.48 \%$ & $28.00 \%$ \\
\hline & Large effect & $36.96 \%$ & $31.48 \%$ & $44.00 \%$ \\
\hline & Very large effect & $19.57 \%$ & $24.07 \%$ & $8.00 \%$ \\
\hline & & $100.00 \%$ & $100.00 \%$ & $100.00 \%$ \\
\hline
\end{tabular}

In AD KTGT Bar for $22.83 \%$ of the examinees, personal needs do not represent work incentive or their effect is small, whereas for $56.53 \%$ of the examinees they have a large or very large effect. In Port of Adria, for $12.97 \%$ of the examinees, personal needs do not 
affect or their effect on work incentive is negligible in comparison to $55.55 \%$ of the examinees for whom they have a large or very large effect. In Luka Bar, personal needs for $20.00 \%$ of the examinees do not affect or minimally affect work incentive, in comparison to $52.00 \%$ of their colleagues for whom personal needs have large or very large effect on work incentive.

Personal needs as work incentives have a large or very large influence on most of the examinees.

\section{- Occupational safety}

Table 5 Work incentives - occupational safety [22]

\begin{tabular}{llccc}
\hline & & AD KTGT Bar & Port of Adria & Luka Bar \\
& & 2015 & 2018 & \multicolumn{1}{c}{2018} \\
\hline \multirow{6}{*}{ Valid } & No effect & $10.87 \%$ & $3.70 \%$ & $16.00 \%$ \\
& Small effect & $16.30 \%$ & $14.81 \%$ & $4.00 \%$ \\
& Medium effect & $31.52 \%$ & $29.63 \%$ & $36.00 \%$ \\
& Large effect & $18.48 \%$ & $18.52 \%$ & $28.00 \%$ \\
& Very large effect & $22.83 \%$ & $33.33 \%$ & $16.00 \%$ \\
\cline { 2 - 5 } & & $100.00 \%$ & $100.00 \%$ & $100.00 \%$ \\
\hline
\end{tabular}

In AD KTGT Bar for $27.17 \%$ of the examinees think that occupational safety is not $\mathrm{t}$ work incentive or its effect is small, whereas $41.31 \%$ think it has a large or very large effect on work incentive. In Port of Adria for $18.51 \%$ of the examinees, occupational safety has no or small effect in comparison to $51.85 \%$ of the examinees for whom it has a large or very large effect on work incentive. In Luka Bar, occupational safety for $20.00 \%$ of the examinees does not affect or minimally affect work incentive, in comparison to $46.00 \%$ of their colleagues for whom occupational safety has large or very large influence on work incentive.

Only for Port of Adria, occupational safety has over half of the majority with large or very large effect, whereas, in AD KTGT Bar and Luka Bar, the medium effect is dominant.

\section{- Work content}

Table 6 Work incentives - work content [22]

\begin{tabular}{llccc}
\hline & & AD KTGT Bar & Port of Adria & Luka Bar \\
& & 2015 & 2018 & \multicolumn{1}{c}{2018} \\
\hline \multirow{6}{*}{ Valid } & No effect & $11.96 \%$ & $7.41 \%$ & $4.00 \%$ \\
& Small effect & $15.22 \%$ & $11.11 \%$ & $8.00 \%$ \\
& Medium effect & $39.13 \%$ & $44.44 \%$ & $28.00 \%$ \\
& Large effect & $15.22 \%$ & $18.52 \%$ & $40.00 \%$ \\
& Very large effect & & $18.52 \%$ & $20.00 \%$ \\
\cline { 2 - 5 } & & $18.48 \%$ & $100.00 \%$ & $100.00 \%$ \\
\hline
\end{tabular}

In AD KTGT Bar, for $27.18 \%$ of the examinees work content does not represent work incentive or its effect is small, whereas for $33.70 \%$ of the examinees it has a large or very large effect on work incentive. In Port of Adria, for $18.52 \%$ of the examinees, work 
content has no or small effect small, in comparison to $37.04 \%$ of the examinees for whom it has large or very large effect as a work incentive. In Luka Bar, work content for $12.00 \%$ of the examinees has no or small effect as work incentive, in comparison to $60.00 \%$ of their colleagues for whom occupational safety has a large or very large effect.

For the examinees in AD KTGT Bar and Port of Adria, work content does not have or has medium effect as a work incentive, whereas for those from Luka Bar it has very large effect.

\section{- Participation in decision making}

Table 7 Work incentives - participation in decision making [22]

\begin{tabular}{|c|c|c|c|c|}
\hline & & $\begin{array}{c}\text { AD KTGT Bar } \\
2015\end{array}$ & $\begin{array}{c}\text { Port of Adria } \\
2018\end{array}$ & $\begin{array}{c}\text { Luka Bar } \\
2018\end{array}$ \\
\hline \multirow{6}{*}{ Valid } & No effect & $36.96 \%$ & $27.78 \%$ & $24.00 \%$ \\
\hline & Small effect & $10.87 \%$ & $9.26 \%$ & $20.00 \%$ \\
\hline & Medium effect & $23.91 \%$ & $33.33 \%$ & $24.00 \%$ \\
\hline & Large effect & $15.22 \%$ & $14.81 \%$ & $24.00 \%$ \\
\hline & Very large effect & $13.04 \%$ & $14.81 \%$ & $8.00 \%$ \\
\hline & & $100.00 \%$ & $100.00 \%$ & $100.00 \%$ \\
\hline
\end{tabular}

In AD KTGT Bar for $47.83 \%$ of the examinees, participation in decision making is not considered as a work incentive or its effect is smalls, whereas for $28.26 \%$ of the examinees it has a large or very large effect on work incentive. In Port of Adria for $37.04 \%$ of the examinees, participation in decision making has no or small effect in comparison to $29.62 \%$ of the examinees for whom it has large or very large effect. In Luka Bar, participation in decision making for $24.00 \%$ of the examinees has no or small effect, whereas for $32.00 \%$ of their colleagues think that it has large or very large effect on work incentive.

Participation in decision making, as a work incentive for the examinees in all three companies, does not have a relevant effect.

\section{CONCLUSION}

The results of the conducted investigation clearly show that "income" is the most important work incentive, i.e. that it has the greatest motivational value in comparison to other six work incentives. Regardless of the time-gap between two questionings, and transformation of the owner's structure as well, it is visible that income remains the most important work incentive.

The second-ranked incentive is permanent employment, and, in terms of percentage, it is very similarly ranked as firstly ranked incentive "income".

Based on this, it can be concluded that the majority of examinees need a rise in salaries and also have worries and fears about earning for a living, which is reflected through the fact that employment is very significant for this group of people.

The incentive "interpersonal relations" is in third place. If the ranking of the abovementioned incentive is observed through the pyramid of Maslow's hierarchy of needs, and bearing in mind that the investigation was conducted in an organization of high risk, 
especially in the context of occupational safety, it becomes clear why interpersonal relations are highly positioned in the third place.

The fourth place is occupied by "occupational safety". However, in Port of Adria for over half of the majority this incentive has large and very large effect, whereas a large number of examinees from AD KTGT Bar and Luka Bar think it has medium effect. Also, it is more significant to the examinees in comparison to "personal needs", which are ranked as the fifth in terms of importance.

The incentive "work content" is ranked sixth because it is relevant only for the examinees from one company, whereas "participation in decision making" does not have relevant influence for the examinees from all three companies, and this is why it is ranked seventh.

The above conclusions, which are obtained and based on the relevant number of examinees in three companies, in a different time frame, can be unambiguously accepted as directions for future management activities in order to increase productivity.

Acknowledgment: The research presented in this paper was financed by the Ministry of Science and Technological Development of Serbia within the projects III 43014 and III 42006.

\section{REFERENCES}

1. Ajzen, I., Czasch, C., Flood, M.G. (2009). From Intentions to Behavior: Implementation Intention, Commitment, and Conscientiousness, Journal of Applied Social Psychology, 39(6), pp. 1356-1372.

2. Andriessen, J.H.T.H (1978). Safe behavior and safety motivation, Journal of Occupational Accidents, 1, pp. 363-376.

3. Bartol, K.M., Martin, D.C. (1998). Management, New York, McGraw-Hill.

4. Clarke, S. (2006). The Relationship between Safety Climate and Safety Performance: A Meta-analytic Review, Journal of Occupational Health Psychology, 11, pp. 315-327.

5. Che Hassan, C.R., Basha, O.J., Wan Hanafi, W.H. (2007). Perception of Building Construction Workers towards Safety, Health and Environment, Journal of Engineering Science and Technology, 2(3), pp. 271-279.

6. Chen, C.F., Chen, S.C. (2014). Measuring the effects of safety management system practices, morality leadership and self-efficacy on pilots' safety behaviours: safety motivation as a mediator, Safety Science, 62, pp. 376-385.

7. Christian, M.S., Bradley, J.C., Wallace, J.C., Burke, M.J. (2009). Workplace safety: A meta-analysis of the roles of person and situation factors, Journal of Applied Psychology, 94, pp. 1103-1127.

8. Dejoy, D.M. (2005). Behavior change versus culture change: Divergent approaches to managing workplace safety, Safety Science, 43, pp. 105-129.

9. Ford, M.T., Tetrick, L.E. (2008). Safety motivation and human resource management in North America, The International Journal of Human Resource Management, 19, pp. 1472-1485.

10. Griffin, M.A., Neal, A. (2000). Perceptions of safety at work: A framework for linking safety climate to safety performance, knowledge, and motivation, Journal of Occupational Health Psychology, 5, pp. 347-358.

11. Griffin, M., Hu, X. (2013). How leaders differentially motivate safety compliance and safety participation: the role of monitoring, inspiring, and learning, Safety Science, 60, pp. 196-202.

12. Hedlund, A., Åteg, M., Andersson, I.M., Rosén, G. (2010). Assessing motivation for work environment improvements: internal consistency, reliability and factorial structure, Journal of Safety Research, 41, pp. $145-151$

13. Hedlund, A., Gummesson, K., Rydell, A., Andersson, I. (2016). Safety motivation at work: Evaluation of changes from six interventions, Safety science, 82, pp. 155-163.

14. Helander, M. (1991). Safety hazards and motivation for safe work in the construction industry, International Journal of Industrial Ergonomics, 8(3), pp. 205-223.

15. Jelić, M.(2005). Menadžment poslovnog sistema. M Power, Banja Luka.

16. Kuieper, U. (1987). Unapređivanje motivacije za zaštitu na radu, Revija rada, 196/1987, str. 21-34.

17. Kwon, O.J., Kim, Y.S. (2013). An analysis of safeness of work environment in Korean manufacturing: the "safety climate" perspective, Safety Science, 53, pp. 233-239. 
18. Leung, M.Y., Chong, A., Ng, S.T., Cheung, M.C.K. (2004). Demystifying Stakeholders' Commitment and its impacts on construction projects, Journal of Construction Management and Economics, 22(7), pp. 701-715.

19. Miljković, J. (1985). Motivisanost za zaštitu na radu, Revija rada, 169/1985.

20. Neal, A., Griffin, M. (2006). A study of the lagged relationships among safety climate, safety motivation, safety behaviour, and accidents at the individual and group levels, Journal of Applied Psychology, 91(4), pp. 946-953.

21. Neal, A., Griffin, M.A., Hart, P.M. (2000). The impact of organizational climate on safety climate and individual behavior, Safety Science, 34, pp. 99-109.

22. Rakić, T. (2018.) Motivacija za bezbednost i zdravlje na radu kao element upravljanja profesionalnim rizikom. Fakultet zaštite na radu u Nišu.

23. Rogers, R.W. (1975). A protection motivation theory of fear appeals and attitude change, Journal of Psychology: Interdisciplinary and Applied, 91, pp. 93-114.

24. Saraswathi, S. (2011). A Study on Factors that Motivate IT and Non-IT Sector Employees: A Comparison, International Journal of Research in Computer Application and Management, 1(2), pp. 72-77.

25. Shadare, O. A., Hammed, T. A. (2009). Influence of work motivation, leadership effectiveness and time management on employees' performance in some selected industries in Ibadan, Oyo State, Nigeria, European Journal of Economics, Finance and Administrative Sciences, 16, pp. 7-17.

26. Stojanović, S., Zdravković, S. (2002). Motivation for occupational safety, Facta universitatis - series: Working and Living Environmental Protection, 2(2), pp. 179-187.

27. Stojanović, S., Zdravković, S., Grozdanović, M. (2003). Motivation for occupational safety, XVth Triennial Congress of the International Ergonomics Conference „Ergonomics in the Digital Age“, IEA 2003, Seul, Korea, Proceedings Vol. 5 on CD.

28. Vidaković, T. (2012). Nematerijalne nagrade i njihov uticaj na motivaciju zaposlenih, Economy and Market Communication Review, 2(1), str. 161-177.

29. Vinodkumar, M.N., Bhasi, M. (2010). Safety management practices and safety behaviour: assessing the mediating role of safety knowledge and motivation, Accident analysis and prevention, 42(6), pp. 2082-2093.

30. Zdravković, S., Stojanović, S. (2002). Motivacija za zaštitu na radu, Revija rada, 305/2002, str. 21-29.

31. Zohar, D. (1980). Safety climate in industrial organizations: theoretical and applied implications, Journal of Applied Psychology, 65(1), pp. 96-102.

32. Živković, S. (2008). Motivacija za zaštitu na radu, Monografija, Fakultet zaštite na radu u Nišu.

33. Weiner, B. (1992). Human Motivation. Methaphors, Theories and Research, Thousand Oaks, Sage Publications, Inc.

34. Ying, L., Zhijia, H., Lianbao, L. (2012). Motivation Mechanism of Accident Prevention in Coal Mine, Procedia Engineering, 43, pp. 174-179.

35. Yusoff, F.W., Kian, T.S., Idris, T.M. (2013). Herzberg's two factors theory on work motivation: does its work for todays environment?, Global Journal of Commerce and Management Perspective, 2(5), pp. 18-22.

\section{UTICAJ ZADOVOLJSTVA ZAPOSLENIH NA BEZBEDNOST I PRODUKTIVNOST}

Zadovoljene potrebe zaposlenih imaju najveći uticaj na njihovu motivisanost za povećanjem produktivnosti. Motivacija je jedna od najvažnijih tema u menadžmentu jer organizacije postižu određene rezultate $i$ ciljeve u onom obimu u kome su zaposleni ostvarili predviđene radne učinke, dok su ti ostvareni radni učinci u direktnoj korelacionoj vezi sa satisfakcijom zaposlenih. Fokus čovekovih delatnosti i njihova pokretačka snaga su upravo kompleksan spoj faktora koje zajedno čine svi pokretači. U nastojanju da se dobije odgovor na pitanje zbog čega se individua ponaša na konkretan način u određenoj situaciji a ne drugačije, potrebno je analizirati motive kao sastavne delove svake ličnosti.

Istraživanje praktičnih načina za otklanjanje ili smanjenje dejstava faktora koji prouzrokuju neželjene motivacije, moguće je putem identifikacije objektivnih podsticaja iz radne sredine. Kako se satisfakcija zaposlenih sastoji od više činilaca, primarni cilj ovog rada je utvrđivanje potreba koje su od izuzetnog značaja za zaposlene a zatim i njihovo rangiranje. Rezultati predstavljeni u ovom radu su deo obimnog istraživanja, sprovedenog prvi put 2014/2015. godine, te ponovljenog 2018. godine, na ukupnom uzorku od 386 ispitanika.

Ključne reči: motivacija, motivacija za zaštitu na radu, podsticaj za rad, zadovoljstvo poslom, produktivnost 